\title{
Relation between the bronchial obstructive response to inhaled lipopolysaccharide and bronchial responsiveness to histamine
}

\author{
Olivier Michel, Roberta Ginanni, Roger Sergysels
}

\begin{abstract}
Background Bronchoconstriction has developed after inhalation of lipopolysaccharide in a dose of $20 \mu \mathrm{g}$ in asthmatic patients and of $200 \mu \mathrm{g}$ in normal subjects. This study set out to determine whether the bronchial response to lipopolysaccharide was related to non-specific bronchial responsiveness and atopy.

Methods Sixteen subjects with a fall in specific airway conductance of $\mathbf{4 0} \%\left(\mathbf{P D}_{40}\right.$ sGaw) after inhaling up to $900 \mu \mathrm{g}$ histamine inhaled $20 \mu \mathrm{g}$ lipopolysaccharide (from Escherichia coli type 026:B6) a week after bronchial challenge with a control solution of saline. The bronchial response over five hours was measured as change in $F E V_{1}$ and area under the $F E V_{1}$ time curve.

Results $\mathrm{FEV}_{1}$ fell significantly more after lipopolysaccharide than after diluent inhalation, the difference in mean (SE) FEV $_{1}$ being $4.6 \%$ (5.4\%); response was maximal 60 minutes after lipopolysaccharide inhalation and lasted more than five hours. Histamine $\mathrm{PD}_{20} \mathrm{FEV}_{1}$ and $P_{40}$ sGaw correlated with the fall in FEV after lipopolysaccharide inhalation. There was no difference in the proportions of responders and non-responders to lipopolysaccharide who were atopic.

Conclusion Lipopolysaccharide induced bronchial obstruction is associated with non-specific responsiveness but not with atopy.
\end{abstract}

Endotoxins are partly formed from the outer cell membrane of Gram negative bacteria and may be shed into the environment surrounding the bacterium. They are potent proinflammatory substances and when inhaled are able to activate various cells in the respiratory tract, including polymorphonuclear leucocytes, ${ }^{1}$ macrophages, ${ }^{23}$ and mast cells ${ }^{4}$; they also activate several proinflammatory mediators, including complement, ${ }^{5}$ arachidonic acid, ${ }^{6}$ and neutrophil enzymes. ${ }^{3}$ Lipopolysaccharides (the major part of endotoxin) have been found in commercial $^{7}$ and natural house dust extracts, raising the possibility that they may cause problems in asthmatic patients.

In normal subjects inhalation of $200 \mu \mathrm{g}$ lipopolysaccharide causes bronchoconstriction. ${ }^{9}$ A dose of $20 \mu \mathrm{g}$ causes no response in normal subjects ${ }^{9}{ }^{10}$ but causes bronchoconstriction in some asthmatic patients, ${ }^{10}$ suggesting that non-specific bronchial responsiveness might be one factor determining the bronchial response to lipopolysaccharide.

The aim of the present study was to determine how the response to inhaled lipopolysaccharide $(20 \mu \mathrm{g})$ is related to bronchial responsiveness to histamine and atopic state.

\section{Methods}

SUBJECTS

We selected for the study 16 student volunteers or patients (nine male, seven female; mean age $42 \cdot 2$ (SD 12.6) years) with a $\mathrm{PD}_{40} \mathrm{sGaw}$ value (a provocation dose of histamine causing a $40 \%$ fall in specific airways conductance) of less than $900 \mu \mathrm{g}$. Asthma was defined according to the American Thoracic Society criteria. ${ }^{11}$ Twelve patients had mild asthma treated with $\beta_{2}$ agonists only; four had perennial rhinitis. The patients' characteristics are shown in table 1.

No patient had had an acute respiratory infection in the month before the study. Four subjects were smokers and were asked to stop smoking 12 hours before each challenge test. None was receiving treatment with antihistamine, corticosteroid, methylxanthine, sodium cromoglycate, or non-steroid antiinflammatory drugs. The asthmatic patients were asked to stop $\beta_{2}$ agonist drugs for 12 hours before each test. All subjects had baseline measurements of forced expiratory volume in one second $\left(\mathrm{FEV}_{1}\right)$ and airway resistance (Raw) within the normal range (that is, the predicted value $\pm 1.65 \mathrm{SD}$, as recommended by the Communauté Europeenne du Charbon et de l'Acier (CECA). ${ }^{12}$

Patients were defined as atopic or non-atopic on the basis of a family history (first degree) of allergic disorders, raised total serum IgE (PRIST, Phadebas; normal values $<200$ IU/ $\mathrm{ml}$ ), raised specific serum IgE (radioimmunoallergosorbent test, Pharmacia), and immediate prick skin test responses to common allergens (Bencard UK).

The study was approved by the ethical committee of Saint-Pierre University Hospital (Université Libre de Bruxelles). Oral informed consent was obtained from each subject.

BRONCHIAL CHALLENGE TESTS

Non-specific bronchial responsiveness was assessed by giving histamine diphosphate solu- 
Table 1 Characteristics of the subjects

\begin{tabular}{|c|c|c|c|c|c|c|c|c|}
\hline $\begin{array}{l}\text { Patient } \\
\text { No }\end{array}$ & Sex & $\begin{array}{l}\text { Age } \\
(y)\end{array}$ & Smoker & Atopic & Diagnosis & $\begin{array}{l}F E V_{1} \\
(\% \text { pred })^{\star}\end{array}$ & $\begin{array}{l}P D_{20} F E V_{1} \\
(\mu g \text { histamine })\end{array}$ & $\begin{array}{l}P D_{40} \text { sGaw } \\
(\mu g \text { histamine })\end{array}$ \\
\hline 1 & $\mathbf{M}$ & 40 & + & + & Asthma & 86 & $46 \cdot 5$ & 24 \\
\hline 2 & $\mathrm{~F}$ & 45 & + & + & Asthma & 72 & 123 & 40 \\
\hline 3 & $\mathrm{~F}$ & 38 & + & - & Asthma & 96 & 819 & 82 \\
\hline 4 & $\mathbf{M}$ & 52 & - & + & Asthma & 100 & 900 & 465 \\
\hline 5 & $\mathbf{M}$ & 63 & - & - & Asthma & 72 & 78 & 36 \\
\hline 6 & $M$ & 43 & - & + & Asthma & 115 & 529 & 248 \\
\hline 7 & $\mathbf{M}$ & 65 & - & - & Asthma & 74 & 712 & 100 \\
\hline 8 & $\mathrm{M}$ & 59 & - & + & Asthma & 77 & 111 & $48 \cdot 5$ \\
\hline 9 & $\mathrm{~F}$ & 33 & - & + & Asthma & 96 & 900 & 168 \\
\hline 10 & $\mathrm{~F}$ & 26 & - & + & Asthma & 90 & 198 & 93 \\
\hline 11 & $\mathbf{F}$ & 38 & - & + & Asthma & 114 & 90 & 66 \\
\hline 12 & $\mathbf{F}$ & 46 & - & - & Asthma & 90 & 108 & 35 \\
\hline 13 & $\mathbf{F}$ & 26 & - & - & Rhinitis & 91 & 900 & 772 \\
\hline 14 & $M$ & 31 & - & + & Rhinitis & 90 & 900 & 360 \\
\hline 15 & $\mathrm{M}$ & 32 & - & - & Rhinitis & 108 & 900 & 834 \\
\hline 16 & $\mathrm{M}$ & 29 & + & + & Rhinitis & 106 & 529 & 228 \\
\hline
\end{tabular}

^Basal $\mathrm{FEV}_{1}$, measured on the day the histamine challenge test was carried out.

$\mathrm{FEV}_{1}$ - forced expiratory volume in one second; $\mathrm{PD}_{20} \mathrm{FEV}_{1}$ - provocation dose of histamine causing a $20 \%$ fall in $\mathrm{FEV}_{1}$; $\mathrm{PD}_{40} \mathrm{sGaw}$-provocation dose of histamine causing a $40 \%$ fall in specific airways conductance.

tion (Hal Products) in increasing concentrations $(1,2,4,8,16,32 \mathrm{mg} / \mathrm{ml})$. Solutions were stored at $4^{\circ} \mathrm{C}$ and allowed to warm to room temperature one hour before use. The control solution was the histamine diluent (a saline $9 \mathrm{~g} / 1$ solution containing phenol, Hal Products).

The lipopolysaccharide solution was prepared with an extract (obtained by the trichloroacetic acid method) of $E$ coli serotype 026:B6 (lot 13 F-4019, Sigma) dissolved in a sterile saline $9 \mathrm{~g} / 1$ solution, after this had been shaken (vortex for two minutes) to a final dilution of $1 \mathrm{mg} / \mathrm{ml}$. Sterile saline $(9 \mathrm{~g} / \mathrm{l})$ was used as a control.

All solutions were administered by a Mefar MB3 dosimeter, which includes a solenoid electrovalve delivering air from a compressor at $1.6 \mathrm{~kg} / \mathrm{cm}^{2}$ during inspiration. The nebuliser was programmed to open for 0.6 seconds, which produces an aerosol of $4 \mu \mathrm{l}$ at each slow inhalation, starting from functional residual capacity to just below total lung capacity (TLC).

All measurements were made in a constant volume computerised body plethysmograph (Bodyscreen II, Jaeger). Raw, specific airway conductance (sGaw), and $\mathrm{FEV}_{1}$ (best of three determinations) were obtained as described..$^{10}$

\section{HISTAMINE CHALLENGE}

Five puffs of control solution were followed by increasing concentrations $(1-32 \mathrm{mg} / \mathrm{ml})$ of histamine solution. Each dose was given at three minute intervals; $\mathrm{FEV}_{1}$ and sGaw were measured two minutes after each inhalation and expressed as percentages of the value after the control solution. ${ }^{13}$ The cumulative provocative doses of histamine inducing a $20 \%$ fall in $\mathrm{FEV}_{1}\left(\mathrm{PD}_{20} \mathrm{FEV}_{1}\right)$ or a $40 \%$ fall in sGaw $\left(\mathrm{PD}_{40} \mathrm{sGaw}\right)$ were calculated from the doseresponse curve. Histamine challenge tests were performed in the two weeks before the bronchial challenge with lipopolysaccharide solvent.

\section{LIPOPOLYSACCHARIDE CHALLENGE}

Subjects were challenged with saline on day 1 and with lipopolysaccharide on day 8 , a single blind procedure being used. The test was started at $0830 \mathrm{~h} . \mathrm{FEV}_{1}$ (best of three values) was measured three times at 15 minute intervals and the mean of these values was taken as the baseline value. After inhalation of five puffs of $4 \mu \mathrm{l}$ each of either solvent or lipopolysaccharide solution (total inhaled lipopolysaccharide dose $20 \mu \mathrm{g}), \mathrm{FEV}_{1}$ was measured at $15,30,60,120,180,240$, and 300 minutes and expressed as a percentage of the baseline value. Patients having a $10 \%$ decrease or more in $\mathrm{FEV}_{1}$ from baseline were admitted overnight for observation; other subjects were discharged home with a telephone contact number in case of deterioration.

Salbutamol $200 \mu \mathrm{g}$ was given at the end of the histamine and lipopolysaccharide challenges.

\section{ANALYSIS}

Results are expressed as means with standard deviations in parenthesis. Differences between groups were tested by Mann-Whitney U test or by $\chi^{2}$ test with Yates's correction. ${ }^{14}$

The differences between values of $\mathrm{FEV}_{1}$ after inhalation of control and lipopolysaccharide solutions were analysed at each time point for each patient. The bronchial response to lipopolysaccharide (from the 15th to the 300th minute) was expressed as the area between the lipopolysaccharide and solvent $\mathrm{FEV}_{1}$-time response (area LPS 15-300) measured by planimetry $\left(60\right.$ minutes $\left.=10 \% \mathrm{FEV}_{1}\right)$. It was also measured as the mean decrease in $\mathrm{FEV}_{1}$ at each time point (LPS 15-300). A two way analysis of variance (with subject and times as factors) was performed on the difference in $F V_{1}$. When the result of the $F$ test was significant, the difference in $\mathrm{FEV}_{1}$ was compared with the baseline difference in $\mathrm{FEV}_{1}$ by the modified $t$ test with the Bonferroni correction. ${ }^{15}$

The significance of the lipopolysaccharide response within subjects was tested by a two way analysis of variance on the $\mathrm{FEV}_{1}$ changes (factors: times and treatment-that is, lipopolysaccharide or solvent). A patient was defined as a significant responder $(R)$ or a nonresponder (NR) according to whether the result of the $\mathrm{F}$ test was significant. 
Figure 1 Mean ( $S E$ ) results of the

lipopolysaccharide (LPS) bronchial challenge test ( $\square-\square$ ) compared with control results (口- $\mathrm{D}$ ) in the 16 $3 \cdot 139, p<0.005 ; S E$ indicated by bars). patients studied $\left(F^{\prime}{ }^{\prime}\right.$
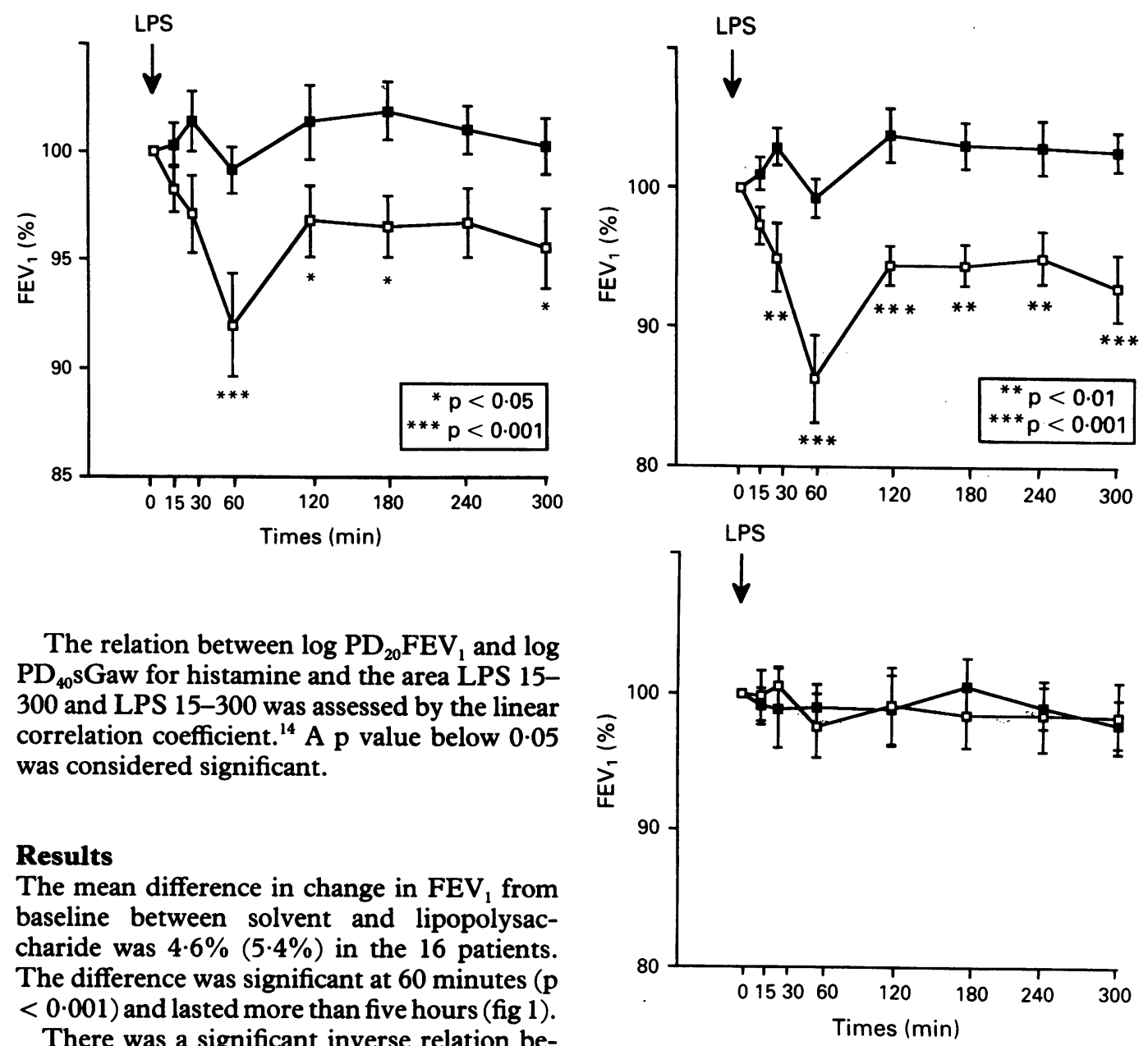

The relation between $\log \mathrm{PD}_{20} \mathrm{FEV}_{1}$ and $\log$ $\mathrm{PD}_{40} \mathrm{sGaw}$ for histamine and the area LPS 15300 and LPS $15-300$ was assessed by the linear correlation coefficient. ${ }^{14} \mathrm{~A}$ p value below $\mathbf{0 . 0 5}$ was considered significant.

\section{Results}

The mean difference in change in $\mathrm{FEV}_{1}$ from baseline between solvent and lipopolysaccharide was $4.6 \%(5.4 \%)$ in the 16 patients. The difference was significant at 60 minutes (p $<0.001$ ) and lasted more than five hours (fig 1).

There was a significant inverse relation between the response to lipopolysaccharide and the response to histamine $(\mathrm{r}=-0.61$ and -0.73 for LPS $15-300 v \log \mathrm{PD}_{20} \mathrm{FEV}_{1}$ (p < $0.02)$ and $\log \mathrm{PD}_{40} \mathrm{sGaw}(\mathrm{p}<0.001) ; \mathrm{r}=$ -0.64 and -0.74 for area LPS $15-300 v \log$ $\mathrm{PD}_{20} \mathrm{FEV}_{1}(\mathrm{p}<0.01)$ and $\log \mathrm{PD}_{40} \mathrm{sGaw}(\mathrm{p}<$ $0.001)$ ).

The group who responded to lipopolysaccharide $(n=8)$ had a mean fall in $\mathrm{FEV}_{1}$ (LPS $15-300)$ of $8.6 \%(3 \cdot 1 \%)$ and a maximal fall at 60 minutes of $12.9 \%$ (6.8\%) (fig 2). Responders and non-responders did not differ significantly in terms of age, sex ratio, baseline $\mathrm{FEV}_{1}$ or proportions of smokers and of atopic individuals (table 2). Responders to lipopolysaccharide had lower values than non-responders for $\mathrm{PD}_{20} \mathrm{FEV}_{1}$ (257 (217) $v 723$ (305) $\mu \mathrm{g}$ histamine; $\mathrm{p}=0.025)$ and $\mathrm{PD}_{40} \mathrm{sGaw}(81$ (71) $v$ 369 (302) $\mu \mathrm{g}$ histamine; $\mathrm{p}=0.027$ ).

Table 2 Comparison of the characteristics of the responders $(R)$ and non-responders (non-R) to lipopolysaccharide

\begin{tabular}{lccl}
\hline & $R$ & Non-R & $p$ \\
\hline n & 8 & 8 & \\
Age (years) & $45 \cdot 4(11 \cdot 3)$ & $39(13 \cdot 8)$ & NS \\
M/F & $3 / 5$ & $6 / 2$ & NS \\
Smokers & 2 & 2 & NS \\
Total IgE $(\mathrm{IU} / \mathrm{ml})$ & $629(461)$ & $404(408)$ & NS \\
Positive skin test response & 4 & 5 & NS \\
Atopic & 5 & 5 & NS \\
Basal FEV $(\%$ predicted) & $89 \cdot 5(18 \cdot 9)$ & $93.9(11 \cdot 1)$ & NS \\
PD $_{20}$ FEV $(\mu \mathrm{g})$ & $257 \cdot 0(271 \cdot 2)$ & $723.3(305 \cdot 5)$ & $0.025^{\star}$ \\
PD $_{40}$ SGaw $(\mu \mathrm{g})$ & $81 \cdot 1(70 \cdot 8)$ & $368 \cdot 8(302 \cdot 1)$ & $0.027^{\star}$ \\
\hline
\end{tabular}

^Mann-Witney U test.

Abbreviations as in table 1 .
Figure 2 Results of the lipopolysaccharide (LPS) bronchial challenge test ( $\square-\square$ ) compared with control results (_- in responders (top panel) and non-responders (bottom panel) to lipopolysaccharide; $F E V$, is expressed as a percentage of the basal value. $A$ two way analysis of variance was applied $\left(F_{49}^{7}=6 \cdot 39\right.$, $p<0.001$, and 0.44, NS; SE indicated by bars) and $p$ values were calculated with Bonferroni correction.

\section{Discussion}

Because of the wide variation in structure and biological activity of endotoxin we studied lipopolysaccharide from $E$ coli as this has shown lung toxicity in vitro and after inhalation in animals ${ }^{1-3616-18}$ and man. ${ }^{10} 19$

There was a wide range of response to lipopolysaccharide amongst the 16 subjects, so the group was divided into lipopolysaccharide responders and non-responders. The main characteristic of the subjects who produced a significant fall in $\mathrm{FEV}_{1}$ after inhaling $20 \mu \mathrm{g}$ lipopolysaccharide was their greater histamine bronchial responsiveness. This is consistent with studies of van der Zwan et al, ${ }^{20}$ who showed that inhalation of Haemophilus influen$z a e$ endotoxin induced decrease in $\mathrm{FEV}_{1}$ only in patients with histamine hyperresponsiveness. In the study of Cavagna et al $^{19}$ inhaling 40 $\mu \mathrm{g}$ lipopolysaccharide induced bronchoconstriction only in patients with chronic bronchitis and not in normal subjects. They found that normal subjects may respond to higher doses of lipopolysaccharide $(80 \mu \mathrm{g})$, as did Rylander et al, ${ }^{9}$ who found bronchoconstriction after inhalation of $200 \mu \mathrm{g}$ lipopolysaccharide but not after $30 \mu \mathrm{g}$. These data suggest 
that the response to lipopolysaccharide is dose related and that sensitivity to lipopolysaccharide is related to non-specific bronchial hyperreactivity, which may be a marker of bronchial inflammation. The correlation between the airway response to lipopolysaccharide and histamine in the present study supports this view.

The fall in $\mathrm{FEV}_{1}$ induced by lipopolysaccharide was seen at 30 minutes, peaked at 60 minutes, and lasted more than five hours; this is consistent with the effect of inhaled lipopolysaccharide in patients with chronic bronchitis ${ }^{19}$ or chronic non-specific lung disease with bronchial hyperreactivity.$^{20}$ The time course of the bronchial response to lipopolysaccharide is also consistent with cell recruitment into the airways after inhalation of endotoxin in animal models. In guinea pigs inhalation of endotoxin caused an influx of neutrophils in the airways at intervals ranging from 90 minutes ${ }^{32122}$ to four hours ${ }^{18}$ and lasting at least 24 hours. $^{31822}$

The fall in $\mathrm{FEV}_{1}$ at 15 minutes was not significant. Absence of the early bronchoconstriction, seen in IgE mediated reactions, suggests that the response to lipopolysaccharide could be mediated by a non-IgE mechanism. This is supported by the presence of a bronchial response to lipopolysaccharide in some non-atopic subjects in the present study, by the absence of an immediate prick skin test response to lipopolysaccharide in atopic subjects, ${ }^{23}$ and by the absence of lipopolysaccharide induced histamine release by basophils from atopic subjects. ${ }^{24}$

Studies in monozygotic and dizygotic twins ${ }^{25}$ suggest that factors determining bronchial responsiveness are mainly exogenous rather than genetic. These may be IgE specific (sensitisation limited to the atopic subjects) or nonspecific (in both atopic and non-atopic subjects). In our study the response to lipopolysaccharide correlated with nonspecific bronchial responsiveness but was independent of the presence or absence of atopy. Lipopolysaccharide could be a factor of clinical relevance in both atopic and non-atopic bronchial diseases like intrinsic and extrinsic asthma, chronic bronchitis, and some occupational lung diseases.

We thank Mrs M J van Gyseghem for technical assistance and Mrs B van Belleghem for secretarial assistance.
1 Helander I, Salkinoja-Salomen M, Rylander R. Chemical structure and inhalation toxicity of lipopolysaccharides from bacteria on cotton. Infect Immunity 1980;29:859-62.

2 Rylander R, Beijer L. Inhalation of endotoxin stimulate alveolar macrophages production of platelet-activating factor. Am Rev Respir Dis 1987;135:83-6.

3 Rylander R, Fogelmark B, Sjostrand M. Free lung cell phagocytosis and lysosomal enzyme activity after inhalation of lipopolysaccharide in guinea-pigs. Agents Action 1985;16:353-8.

4 Church MK, Pao GJK, Holgate ST, Norn S. Histamine release from human mast cells induced by bacterial cell wall products [abstract]. Ann Allergy 1985;55:272.

5 Von Essen SG, Robbins RA, Thompson AB, Ertl RF Linder J, Rennard S. Mechanisms of neutrophil recruitment to the lung by grain dust exposure. Am Rev Respir Dis 1988;138:921-7.

6 De Maria TF, Burrell R. Effects of inhaled endotoxincontaining bacteria. Environ Res 1980;23:87-9.

7 Siraganian RP, Baer H, Hochstein HD, May JC. Allergenic and biologic activity of commercial preparations of house dust extract. J Allergy Clin Immunol 1979;64:526-33.

8 Michel O, Ginanni R, Duchateau J, Vertongen F, Le Bon B, Sergysels R. Domestic endotoxin exposure and clinical Sergysels R. Domestic endotoxin exposure and clinic

9 Rylander R, Bake B, Fisher JJ, Helander IM. Pulmonary function and symptoms after inhalation of endotoxin. $A m$ Rev Respir Dis 1989;140:981-6.

10 Michel O, Duchateau J, Sergysels R. Effects of inhaled endotoxin on bronchial reactivity in asthmatic and norma subjects. J Appl Physiol 1989;66(3):1059-64.

11 American Thoracic Society. Standards for the diagnosis and care of patients with chronic obstructive pulmonary disease (COPD) and asthma. Am Rev Respir Dis 1987; 136:225-44.

12 Quanjer Ph. Standardized lung function testing. Bull Eur Physiopath Resp 1983;19(5):1-95.

13 Chung KF, Morgan B, Keyes SJ, Snashall PD. Histamine dose-response relationships in normal and asthmatic subjects. Am Rev Respir Dis 1982;126:849-54.

14 Swinscow TDV. Statistics at square one. 3rd ed. London British Medical Association, 1978.

15 Wallenstein S, Zucker CL, Fleiss JL. Some statistical methods useful in circulation research. Circ Res 1980 47:1-9.

16 Burrell R, Rylander R. Further studies on inhaled endotoxin-containing bacteria. Environ Res 1982;27: 325-36.

17 Helander I, Saxen H, Salkinoja-Salomen M, Rylander R Pulmonary toxicity of endotoxins: comparison of lipopolysaccharides from various bacterial species. Infect Immun 1982;35:528-32.

18 Venaille T, Snella MC, Holt PG, Rylander R. Cell recruitment into lung wall and airways of conventional and pathogen-free guinea-pigs after inhalation of endotoxin. Am Rev Respir Dis 1989;139:1356-60.

19 Cavagna G, Foa V, Vigliani EC. Effects in man and rabbits of inhalation of cotton dust or extracts and purified endotoxins. Br J Ind Med 1969;26:314-61.

20 Van der Zwan JC, Orie NGM, Kauffman HF, Wiers PWJ, de Vries $K$. Bronchial obstructive reactions after inhalation with endotoxin and precipitinogens of Haemophilus tion with endotoxin and precipitinogens of Haemophilus
inflenzae in patients with chronic non-specific lung disinflenzae in patients with chronic
ease. Clin Allergy 1982;12:547-59.

21 Pauwels R, Peleman P, Van der Straeten M. Airway inflammation and non-allergic bronchial responsiveness. Eur J Respir Dis 1986;144:137-62.

22 Snella MC, Rylander R. Endotoxin inhalation induces neutrophil chemotaxis by alveolar macrophages. Agents Actions 1985;16:521-6.

23 Michel O, Ginanni R, Le Bon B, Duchateau J. Effects of endotoxin contamination of antigen extract on the

24 Smith TF, Aelvoet M, Morrison DC. The effect of bacterial lipopolysaccharide (LPS) on histamine release from human basophils. Clin Immunol Immunopathol 1985; human bas

25 Zamel N, Leroux M, Vanderdoelen JL. Airway response to inhaled methacholine in healthy non smoking twins. $J$ Appl Physiol 1984;56:936-9. 